\title{
Anti-Corrosion Test on Basal Slope Protection Materials
}

\author{
Ronglan Zhang \\ Institute of Technology, School of Civil Engineering, Yancheng, China \\ Email: z71rl@126.com
}

Received 20 October 2015; accepted 25 December 2015; published 28 December 2015

Copyright (C) 2016 by author and Scientific Research Publishing Inc.

This work is licensed under the Creative Commons Attribution International License (CC BY).

http://creativecommons.org/licenses/by/4.0/

(c) (i) 0pen Access

\begin{abstract}
Through the introduction of the anti-corrosion test schemes, the test equipments and the test procedure for three kinds of basal slop protection materials including fence, mixed stump and geo-textile, this paper comes to a conclusion about the analysis of the anti-corrosion test, revealing that among all of the common basal slop protection materials, mixed stump and fence are with Class II anti-corrosion property, while the geo-textile is with the first-class anti-corrosion property.
\end{abstract}

Keywords

Anti-Corrosion, Stump, Equipment, Procedure

\section{Introduction}

Due to the unique functions of waveresistance, waterproof erosion, greening of environment, landscaping and good harmonization with the surrounding environment in addition to the excellent social benefits, ecological slope protection that has become a new trend of slope protection represents the development trend of the channel slope protection. In China, most of the achievements on ecological slope protection are macroscopically classified into qualitative research, based on which designs and constructions rely heavily on the engineering practices and experiences without quantitative analysis and assessment, which will bring some difficulties in the design, construction, maintenance and management of the ecological slope protection. Actually regarding one of the critical technical problems in ecological slope protection, few researches have been made on the durability of the basal slope protection materials (such as fence, timber pile and mixed stump etc., which are the perishable materials soaked permanently in water) on the riverside slope in the area where water flow varies.

\section{Schemes for the Anti-Corrosion Test}

In order to study the corrosion resistance [1]-[7] of the basal slope protection materials, this paper conducts in- 
door anti-corrosion tests separately on the fence, the mixed stump and the geo-textile that have been coated with corrosionremover or without the application of corrosionremover.

Choose 8 - 9 pieces of the raw materials of the fences and mixed stumps as the test materials, from which select the uniform heartwood cross-sections to prepare at least 12 specimens with a size of $20 \mathrm{~mm} \times 20 \mathrm{~mm} \times 10$ mm each.

The corrosionremoveradopted Shenfeng woodpreservative, which is imported from German made of superior raw materials without harmful substances such as benzene, formaldehyde, lead, mercury, arsenic, $\mathrm{Cr}$ and VOC etc. conforming to the standards of GB/T1723-1993, GB/T1728-1998 and GB/18582-2001.

\section{Specifications for the Anti-Corrosion Test}

This test is conducted based on the standard of GB 13942.1-2009-T Durability of Wood Part 1: Method [8] for laboratory test of natural decay resistance.

\section{Equipments Used in the Anti-Corrosion Test}

The autoclave sterilizer: Design the pressure to be $0.25 \mathrm{MPa}$ and the temperature is $138^{\circ} \mathrm{C}$ in an inoculation chamber or cleanbench. The bacteria culture chamber or the electro-heating standing-temperature cultivator: The temperature is $(28 \pm 2)^{\circ} \mathrm{C}$ and the relativehumidity is $75 \%-85 \%$ with the analyticalbalance: $0.01 \mathrm{~g}$ and the culture flask: $500 \mathrm{ml}$ in addition to the application of a wide-necked triangularflask or a wide-necked dome bottle with thread cap (The minimum capacity is $250 \mathrm{ml}$ and the minimum caliber is $32 \mathrm{~mm}$ with the adoption of thread cap for sterilization). Choose around 2 - 3 logs (DBH: 180 - $350 \mathrm{~mm}$ ) from 3 - 5 trees at a height of 1m above the breast height as the test materials. All of the specimens are equal in size from the uniform heartwood cross-section of every tree with all of the samples taken from the heartwood section near to the pith of every healthy tree without any visible defect: The specimens must be very smooth on all sides without any visible defect. Also it's necessary to prepare at least 12 external heartwoods (equal in size from $2-3$ logs) in a size of 20 $\mathrm{mm} \times 20 \mathrm{~mm} \times 10 \mathrm{~mm}$ each (in the graindirection). As to the cultivated wood, adopt the massonpine sap wood with the size of the cross section the same with or slightly larger than that of the specimen with a thickness of 3 $5 \mathrm{~mm}$ ). Regarding the tested strains: (In the test of the coniferous wood: Rot poria or Gloeophyllum trabeum Murr, and in the test of the broad-leaved wood: Coriolus versicolor or Gloeophyllum trabeum Murr).

\section{Procedure of the Anti-Corrosion Test}

\subsection{Preparation of the Maltose Agarmedium and the River Sand \& Sawdust Medium}

Pour $100 \mathrm{ml}$ of the maltitol solution (Baume degree: 1.03, same below) and 1.5\% - 2.0\% of the agar into a $500 \mathrm{ml}$ narrow-necked flask, which will be placed in a steamsterilizer (Pressure: $0.1 \mathrm{MPa}$ and Temperature: $121^{\circ} \mathrm{C}$, same below) for 30 minutes of sterilization after it has been gagged with a tampon and wrapped in waterproof paper. Then cool the flask in the aseptic inoculation room until it won't burn the hands to pour the medium separately into five sterilized (same above) culture dishes (with a diameter of $9 \mathrm{~cm}$ ). After the medium becomes cooled and coagulated, perform the inoculation process and place the dishes into a bacteria culture chamber or incubator (Temperature: $28^{\circ} \mathrm{C} \pm 2^{\circ} \mathrm{C}$ and relative air humidity: over $75 \%$, same below) for 6 - 7 days of cultivation.

Add the followings into a $500 \mathrm{ml}$ wide-necked flask: $150 \mathrm{~g}$ of cleaned dry river sand (20 - 30 meshes), $15 \mathrm{~g}$ of sapwood saw dust from massonpine (20 - 30 meshes), $8.5 \mathrm{~g}$ of cornflour and $1 \mathrm{~g}$ of brownsugar, all of which will be well mixed and placed with 3 cultivated woods (separated from each other) on the surface. After that, pour slowly $100 \mathrm{ml}$ of maltitol solution into the flask, which will be placed in a high temperatures teamsterilizer (under the same conditions stated above) for 1 hour of sterilization after it has been gagged with a tampon and wrapped in waterproof paper. Then cool the flask in the aseptic inoculation room or the cleanbench for inoculation purpose. In the case that a wide-necked dome bottle with thread cap is adopted, apply the followings into it: $75 \mathrm{~g}$ of cleaned dry river sand (20 - 30 meshes), $7.5 \mathrm{~g}$ of sapwood saw dust from massonpine (20 - 30 meshes), $4.3 \mathrm{~g}$ of cornflour and $0.5 \mathrm{~g}$ of brownsugar, all of which will be well mixed and placed with 2 cultivated woods (separated from each other) on the surface. After that, pour slowly $50 \mathrm{ml}$ of maltitol solution into the bottle, which will be placed in a high temperatures teamsterilizer (under the same conditions stated above) for 1 hour of sterilization after the bottle cap has been tightly fastened. Then cool the bottle in the aseptic inoculation room or 
the cleanbench for inoculation purpose. As to the culture flask with thread cap, slightly unfasten the cap before the sterilization to allow the steam to enter into the bottle. Figure 1 and Figure 2 show both of the medium and the culture dish used in the experiment.

\subsection{Inoculation}

Inoculate the river sand medium with a hypha block, which is $5 \mathrm{~mm}$ in diameter and has been cut off by a sterilepuncher, at the center after the hyphae have grown in the culture dish for 7 - 10 days. Figure 3 shows the inoculation operation performed by the tester in the asepticconditions.

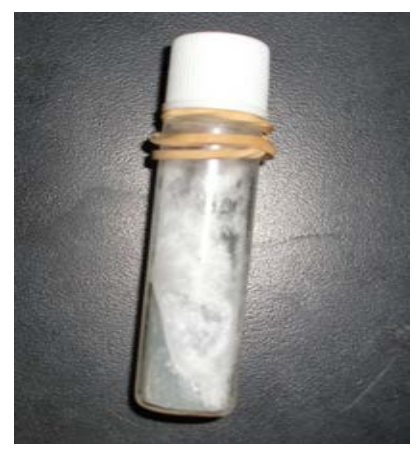

Figure 1. Image of the medium.

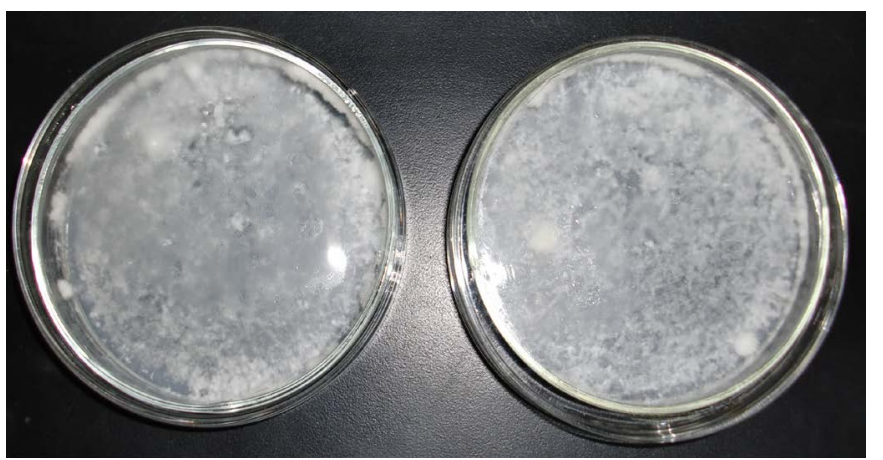

Figure 2. The culture dish containing medium.

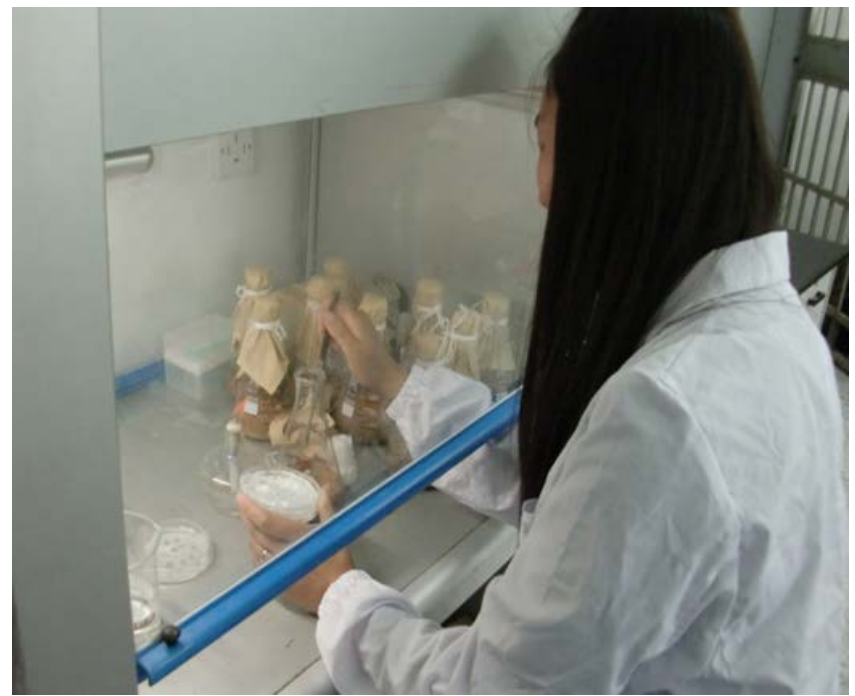

Figure 3. The inoculation operation performed by the tester. 


\subsection{Cultivation}

After the inoculation, place the culture flask in the inocula, where the temperature is $(28 \pm 2)^{\circ} \mathrm{C}$ and the relative air humidity is $75 \%-85 \%$ for around 10 days of bacterial culture. As soon as the mycelium has permeated the medium in the flask, add the specimens in the flask for bacterium infection.

\subsection{Specimen Preparation}

Prepare at least 12 specimens that are numbered and place them in an $\left(103^{\circ} \mathrm{C} \pm 2^{\circ} \mathrm{C}\right)$ oven for roasting until the specimens show constant weight. Weigh every specimen (exact to $0.01 \mathrm{~g}$ ), which should be packed tightly in damping paper (or multilayer gauze), and then place them in the steamsterilizer for around 30 minutes under the normal pressure condition until the moisturecontent of the specimens reaches $40 \%-60 \%$. After that, cool the specimens for further utilization.

\subsection{Bacteria Corrosion on Specimens}

Place the well-prepared specimens onto feeding wood (whose textures are perpendicular to the direction of mycelialgrowth) that have been covered with mycelium in the culture flask under the asepticcondition. After that, locate the culture flask in the bacteria culture chamber (under the same conditions stated above) for 12 weeks of bacterium infection. In the case that a wide-necked dome bottle with thread cap is adopted, slightly unfasten the cap of the bottle to allow the inflow of a little amount of air before the bottle is placed into the bacteria culture chamber.

\subsection{Preparation of the Control Samples}

Since coniferous wood is adopted in the anti-corrosion test, then adopt the Masson pine sapwood (or the other conifer sapwood that shows poor decay resistance) to prepare at least 12 pcs of the control samples as shown in Figure 4 with the test procedure as stated above.

\subsection{Specimen Inspection at the End of the Experiment}

Take out of the specimens as shown in Figure 5 in 12 weeks after the experiment, and remove slightly the mycelium and the dross from the surface of the specimens, which will then be placed in an $\left(103^{\circ} \mathrm{C} \pm 2^{\circ} \mathrm{C}\right)$ oven for roasting until the specimens show constant weight. Make sure to weigh every specimen separately.

\section{Analysis on the Result of the Anti-Corrosion Test}

After the corrosion, we calculate the mass loss rate that is expressed as a percentage of every specimen, the rate with the formula provided as below:

$$
\text { Mass loss rate of a specimen }=\left(W_{1}-W_{2}\right) / W_{1} \times 100 \%
$$

where $W_{1}$ is the mass of the full-dry specimen before the experiment and $W_{2}$ is the mass of the full-dry specimen after the experiment.

Tables 1-4 give the results obtained in the anti-corrosion test.

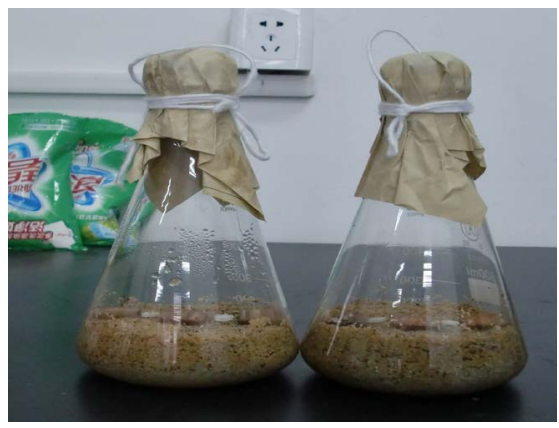

Figure 4. Control samples. 


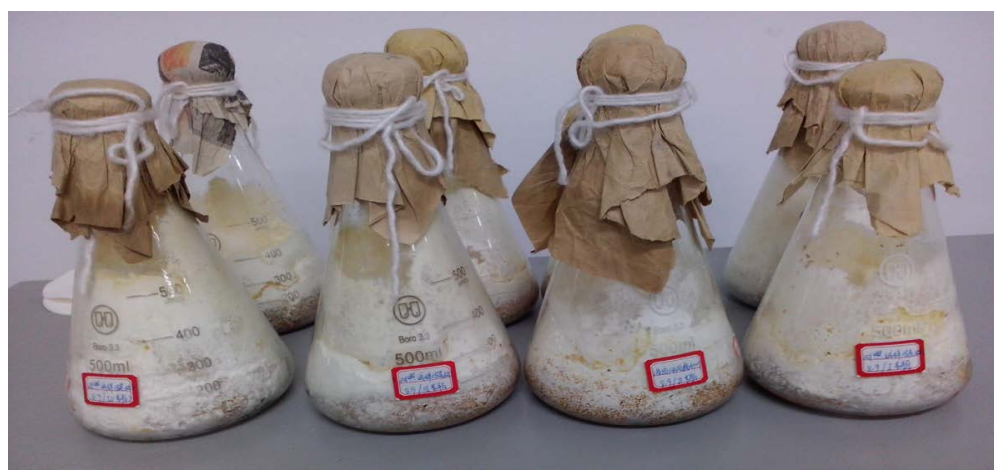

Figure 5. Complete image of the specimens in 12 weeks after the experiment.

Table 1. Results of the anti-corrosion test about the specimen of coniferous wood (mixed stump) without the preservative treatment.

\begin{tabular}{cccccc}
\hline Test Date & Test specimen & No. & $\begin{array}{c}\text { Weight before } \\
\text { the test (g) }\end{array}$ & $\begin{array}{c}\text { Weight after the } \\
\text { test (g) (12 wks later) }\end{array}$ & Weight loss ratio (\%) \\
\hline & I-1 & 2.62 & 2.53 & 1.71 & 1.12 \\
& I-2 & 2.10 & 2.21 & 16.41 \\
& I-3 & 2.65 & 2.42 & 15.96 \\
8.9 & II-4 & 2.63 & 1.98 & 23.25 \\
& II-5 & 2.58 & 2.67 & 1.95 & 26.74 \\
Coniferous wood & II-6 & 2.50 & 2.13 & 14.68 \\
preservative & III-7 & 2.56 & 2.14 & 16.21 \\
& III-8 & 2.68 & 2.14 & 19.96 \\
& III-9 & 2.64 & 2.01 & 23.75 \\
& IV-10 & 2.59 & 1.98 & 23.43 \\
\hline
\end{tabular}

Table 2. Results of the anti-corrosion test about the preservative-treated specimen of the coniferous wood (mixed stump).

\begin{tabular}{|c|c|c|c|c|c|}
\hline Test Date & Test specimen & No. & $\begin{array}{l}\text { Weight before } \\
\text { the test (g) }\end{array}$ & $\begin{array}{l}\text { Weight after the } \\
\text { test (g) (12 wks later) }\end{array}$ & $\begin{array}{l}\text { Weight loss } \\
\text { ratio (\%) }\end{array}$ \\
\hline \multirow{12}{*}{8.8} & \multirow{12}{*}{$\begin{array}{l}\text { Preservative-treated } \\
\text { specimen of } \\
\text { coniferous wood } \\
\text { (mixed stump) }\end{array}$} & $\mathrm{I}-1$ & 2.60 & 2.44 & 5.96 \\
\hline & & $\mathrm{I}-2$ & 2.06 & 1.19 & 41.89 \\
\hline & & $\mathrm{I}-3$ & 2.06 & 1.60 & 21.94 \\
\hline & & II-4 & 2.72 & 2.44 & 10.25 \\
\hline & & II-5 & 2.65 & 2.21 & 16.56 \\
\hline & & II-6 & 2.68 & 2.59 & 3.35 \\
\hline & & III-7 & 2.64 & 2.23 & 15.37 \\
\hline & & III-8 & 2.50 & 2.09 & 16.2 \\
\hline & & III-9 & 2.56 & 2.11 & 17.5 \\
\hline & & IV-10 & 2.57 & 2.17 & 15.56 \\
\hline & & IV-11 & 2.57 & 2.23 & 13.15 \\
\hline & & IV-12 & 2.62 & 2.17 & 16.87 \\
\hline
\end{tabular}


Table 3. Results of the anti-corrosion test about the fence specimen.

\begin{tabular}{|c|c|c|c|c|c|}
\hline Test Date & Test specimen & No. & $\begin{array}{l}\text { Weight before } \\
\text { the test (g) }\end{array}$ & $\begin{array}{l}\text { Weight after the } \\
\text { test (g) (12 wks later) }\end{array}$ & $\begin{array}{c}\text { Weight loss } \\
\text { ratio (\%) }\end{array}$ \\
\hline \multirow{4}{*}{$\begin{array}{c}\text { Inoculation } \\
\text { treatment } \\
\text { on Nov. } 13\end{array}$} & \multirow{4}{*}{$\begin{array}{l}\text { specimens in each } \\
\text { group of fences } \\
\text { without preservative } \\
\text { treatment }\end{array}$} & Group 1 & 6.42 & 5.38 & 16.10 \\
\hline & & Group 2 & 6.55 & 5.47 & 16.42 \\
\hline & & Group 3 & 6.55 & 5.87 & 10.40 \\
\hline & & Group 4 & 6.73 & 5.91 & 12.11 \\
\hline \multirow{4}{*}{$\begin{array}{c}\text { Inoculation } \\
\text { treatment } \\
\text { on Nov. } 13\end{array}$} & \multirow{4}{*}{$\begin{array}{l}3 \text { specimens in each } \\
\text { group of } \\
\text { preservative-treated } \\
\text { fences }\end{array}$} & Group 1 & 5.60 & 4.99 & 10.84 \\
\hline & & Group 2 & 6.39 & 5.91 & 7.52 \\
\hline & & Group 3 & 6.7 & 5.97 & 10.85 \\
\hline & & Group 4 & 6.71 & 6.21 & 7.50 \\
\hline
\end{tabular}

Table 4. Results of the anti-corrosion test about the geo-textile specimen.

\begin{tabular}{|c|c|c|c|c|c|}
\hline Test Date & Test specimen & No. & $\begin{array}{l}\text { Weight before } \\
\text { the test (g) }\end{array}$ & $\begin{array}{l}\text { Weight after the test (g) } \\
\text { (12 wks later) }\end{array}$ & $\begin{array}{l}\text { Weight loss } \\
\text { ratio }(\%)\end{array}$ \\
\hline \multirow{10}{*}{$\begin{array}{c}\text { Inoculation } \\
\text { treatment } \\
\text { on Oct. } 31\end{array}$} & \multirow{10}{*}{$\begin{array}{l}\text { Geo-textile } \\
\text { without } \\
\text { preservative } \\
\text { treatment }\end{array}$} & Group 1 & 0.462 & 0.453 & 1.92 \\
\hline & & Group 2 & 0.486 & 0.468 & 3.58 \\
\hline & & Group 3 & 0.476 & 0.458 & 3.78 \\
\hline & & Group 4 & 0.491 & 0.477 & 2.85 \\
\hline & & Group 5 & 0.482 & 0.465 & 3.52 \\
\hline & & Group 6 & 0.486 & 0.47 & 3.29 \\
\hline & & Group 7 & 0.518 & 0.502 & 2.93 \\
\hline & & Group 8 & 0.514 & 0.501 & 2.52 \\
\hline & & Group 9 & 0.485 & 0.467 & 3.60 \\
\hline & & Group 10 & 0.492 & 0.468 & 4.87 \\
\hline \multirow{4}{*}{$\begin{array}{c}\text { Inoculation } \\
\text { treatment } \\
\text { on Nov. } 17\end{array}$} & \multirow{4}{*}{$\begin{array}{l}\text { Preservative-treated } \\
\text { geo-textile }\end{array}$} & Group 1 & 0.436 & 0.433 & 0.48 \\
\hline & & Group 2 & 0.465 & 0.458 & 1.31 \\
\hline & & Group 3 & 0.426 & 0.423 & 0.70 \\
\hline & & Group 4 & 0.445 & 0.4398 & 1.16 \\
\hline
\end{tabular}

The experimental result shows that the mass loss rate of the mixed stump specimen varies within the range of $14.68 \%$ - 26.74\% with the average value at 19.94\%, indicating that this specimen is corrosion resistant with Class II anti-corrosion property. The mass loss rate of the fence specimen varies within the range of $10.40 \%$ $16.43 \%$ with the average value at $13.76 \%$, indicating that this specimen is corrosion resistant with Class II anti-corrosion property. The mass loss rate of the geo-textile specimen varies within the range of $1.93 \%-3.78 \%$ with the average value at $3.29 \%$, indicating that this specimen has strong corrosion resistance with the first class anti-corrosion property.

Also the experimental result shows that when the specimens are coated with preservative, the mass loss rate will be decreased to some extent within a small range. Actually, the mass loss rate of the preservative-treated mixed stump varies in a range of $10.26 \%$ - $17.50 \%$ with the average value at $15.19 \%$, which is decreased by 23.8\% compared with the mass loss rate of the specimen that hasn't been coated with preservative. As to the preservative-treated fence specimen, the mass loss rate varies in a range of $7.50 \%-10.85 \%$ with the average value at $9.18 \%$, which is decreased by $33.3 \%$ compared with the mass loss rate of the specimen that hasn't been 
coated with preservative. Regarding the mass loss rate of the geo-textile specimen, it varies in a range of $0.48 \%$ $-1.31 \%$ with the average value at $0.916 \%$, which is decreased by $72.1 \%$ compared with that of the specimen, which hasn't been coated with preservative.

Moreover, the experimental result shows that among all of the common basal slop protection materials, mixed stump and fence are with Class II anti-corrosion property, while the geo-textile is with the first-class anti-corrosion property. Then in order to improve the long-term corrosion resistance of the basal slop and to protect the basal slop from ineffective protection, it's necessary to take the corrosion-resistant characters of different basal slop protection materials into account so that a reasonable protection material can be selected in the design.

\section{References}

[1] Wang, Z.Y., et al. (2011) A Comparative Study on Several Anti-Corrosion Materials for Power FGD System. Engineering, 3, 653. http://dx.doi.org/10.4236/eng.2011.36078

[2] Yue, K., et al. (2011) Chemical Modification of Fast-Growing Poplar Wood Mechanical Properties and the Influence of the Natural Durability. Journal of Anhui Agricultural University, 6, 61-64.

[3] Cao, J.Z. (2006) Wood Preservation Technology and the Research Status Quo Abroad. Scientia Silvae Sinicae, Beijing.

[4] Gongping.(2012) Salix psammophila Corrosion Process and Corrosion Resistant Effect Research. PhD Thesis, Inner Mongolia Agricultural University, Inner Mongolia.

[5] Shi, J.L., Kocaefe, D., Amburgey, T. and Zhang, J.L. (2007) A Comparative Study on Brown-Rot Fungus Decay and Subterranean Termite Resistance of Thermally-Modified and ACQ-C-Treated Wood. Holz als Roh- und Werkstoff, 65, 353-358.

[6] Barnes, H.M. and Murphy, R.J. (1995) Wood Preservation: The Classics and the New Age. Forest Products Journal, 45, 16-26.

[7] Bruce, A., King, B. and Highley, T.L. (1991) Decay Resistance of Wood Removed from Poles Biologically Treated with Trichoderma. Holzforschun, 45, 307-311.

[8] China National Standardization Management Committee (1992) Durability of Wood—Part 1: Method for Laboratory test of Natural Decay Resistance. China Standard Publishing House, Beijing. 